\title{
Lise Öğretmenlerinin Örgütsel Ve Bireysel Değerleri
}

DOI: $10.26466 /$ opus.469281

\author{
$\underline{\text { Davut Nacar }^{*}}$ - Zülfü Demirtaş ${ }^{* *}$ \\ *Öğr. Gör., Kahramanmaraş Sütçü İmam Üniversitesi, Sağlık Hizmetleri Meslek Yüksek Okulu, \\ Dulkadiroğlu / Kahramanmaraș / Türkiye \\ E-Posta: davutncr2007@gmail.com ORCID: 0000-0002-0137-4923 \\ ${ }^{*}$ Doç. Dr., Fırat Üniversitesi, Eğitim Fakültesi, Elazı̆̆/ Türkiye \\ E-Posta: zulfudemirtas@gmail.com ORCID: 0000-0002-1072-5772
}

\section{Öz}

Bu çalışmada, lise öğretmenlerinin örgütsel ve bireysel değer algı düzeylerine bakılmıştır. Araştırma olayları ve olguları geçmişte ya da halen olduğu gibi betimlemeyi amaçlayan tarama modeliyle tasarlanmıştır. Araştırmanın evrenini Kahramanmaraş merkez 12 Şubat ve Dulkadiroğlu ilçesinde 2016-2017 eğitim öğretim yılında liselerde görev yapan öğretmenler oluşturmaktadır. Araştırmaya dâhil edilen 303 öğretmene Değerlere Göre Yönetim Ölçeği'nin, Demirtaş ve Ekmekyapar (2012) tarafından açımlayıcı ve doğrulayıcı faktör analizi yapılmış formu kullamılmıştır. Örgütsel Değerler ölçeğinden elde edilen müdür yardımcısı ve öğretmen algılarının sözlü ifadeler hâline dönüştürülmesi için aralık değerleri hesaplanmış; katılımcıların değerlere yönelik algıları ortalamanın üzerinde çıkmıştır. Araştırmada cinsiyet, yapılan görev, yaş ve hizmet yılı değişkenine göre öğretmenlerin örgütsel ve bireysel değer algılarında anlamlı bir fark bulunamamıştır. İlçe değişkenine göre öğretmenlerin örgütsel ve bireysel değer algılarında anlamlı bir fark bulunmuştur.

Anahtar Kelimeler: Öğretmen, Değer, Örgütsel Değer, Bireysel Değer

OPUS (c) Uluslararası Toplum Araştırmaları Dergisi-International Journal of Society Researches ISSN:2528-9527 E-ISSN : 2528-9535

http://opusjournal.net 


\title{
Organizational and Individual Values of High School Teachers
}

\begin{abstract}
In this study, the organizational and individual perception levels of high school teachers were examined. It is designed with a screening model that aims to describe research events and events as if they were past or present. The universe of the research is composed of the teachers working in the high schools in the province of Kahramanmaraş in the district of On İki Şubat and Dulkadiroğlu in the education year of 2016-2017. 303 teachers who were included in the survey have used the form of the Management Scale According to Values, Demirtaş and Ekmekyapar (2012), in which explanatory and confirmatory factor analysis was applied. Interval values were calculated in order to transform the manager and teacher perceptions obtained from Organizational Values scale into oral expressions; perceptions of participants' values were above the average. According to the variables of sex, duty, age and years of service, there was no significant difference in teachers' organizational and individual values perceptions. A significant difference was found in teachers' organizational and individual value perceptions according to district variable.
\end{abstract}

Keywords: Teacher, Value, Organizational Value, Individual Value

OPUS @ C Uluslararası Toplum Araştırmaları Dergisi-International Journal of Society Researches ISSN:2528-9527 E-ISSN : 2528-9535

http://opusjournal.net 


\section{Giriş}

Kültürel, sosyal, ekonomik ve teknolojik değişimlerin çok hızlı olduğu günümüzde, bu değişimlere uyum sağlamada zorluklar yaşanmaktadır. Modern zamanlarda en çok duyduğumuz ve kullandığımız ifadelerden birisi "değerlerin yitirilmesi" ve "değerlerin aşınması" şeklinde ifade edilen bireyin topluma ve kendine yabancılaşmasıdır (Yapıcı ve Zeren Nalinci, 2015, s.75). Örgütün ve bireyin davranışları için toplumsal değişmede öne çıkan değerlerin önemi her geçen gün artmaktadır (Altunay ve Yalçınkaya, 2011). Araştırmacılar tarafından değer farklı farklı tanımlanmıştır. Rokeah (1968, s.5)' a göre değer, "toplumsal ve kişisel belli bir davranış biçiminin ya da varoluş durumunun, zıt bir davranış biçimi ya da varoluş durumu karşısında tercih edilebilir olduğu ile ilgili süregelen inanç" tır. Bu tanımlamaya göre bir değer, günlük yaşamımızdaki amaçlarımıza hizmet eden bir standart veya bir kriterdir: o nasıl davranacağımızı veya bir şeyi nasıl ifade edeceğimizi bize söyleyen; o ahlaki aç1dan bizim davranışlarımızı diğerleriyle karşılaştırmamıza yarayan bir standarttır (Rokeach, 1968: 550; Tolay ve Yeşil, 2016: 40). Değer, bireyin ya da toplumun olmasını arzuladığı durum olarak görülebilir. Meslek olarak kabul edilen bütün uğraş alanlarının kendine özgü değerleri vardır ve her mesleğin üyesi bu değerlere göre davranışta bulunur (Aydın, 2016, s.4).

Sosyal yaşamda ve örgütlerde kurallar ve karşılıklı ilişkiler bireylerin toplumsallaşmalarını ve yeni davranışlar öğrenmelerini sağlamaktadır (Boyacı ve Güven, 2017, s. 55; Taymur ve Türkçapar, 2012, s.155). İnsanın içinde bulunduğu çevrenin ve kişilik özelliklerinin bireyin davranışlarını şekillendirdiği araştırmacılar tarafından vurgulanmaktadır (Robins ve Judge'den aktaran Doğan, 2013, s.17). Bireylerin bilinçli veya bilinçsiz bir şekilde zihinlerine kodladıkları yapılar, onların sahip oldukları değerleri oluştururlar. Bireylerin sahip oldukları değerler, onların çevreden gelen uyarıcıları nasıl algılayacaklarını veya bu uyarıcılara ne şekilde tepkiler vereceklerini belirler (Alev ve Karakuş, 2016, s.140). Okullarda çalışan farklı değer yapılarına sahip olan insanlar, farklı olan değerlerini de okula taşırlar. Çalışanların okullara taşıdıkları bu farklı değerler, örgütsel değerlerin de farklı algılanmasına ve çatışmalara sebep olabilir (Memduhoğlu, 2011, s.39). Bu görüşü destekler nitelikte Turgut (1998), idareci- 
ler ile çalışanlar arasındaki çatışmanın en önemli sebeplerinden birisinin farklı değer algıları olduğunu öne sürmektedir.

Örgütsel yaşamda değerlerin, işgörenin ve örgütün davranışları açısından önemli olduğu düşünülmekte ve bu önem giderek artmaktadır (Taştan, 2010, s.116). Örgütsel değerler, örgütün amaçlarına uygun faaliyette bulunmasına ve başarısının da artmasına katkı sağlayan araçlardır (Tutar, 2016). Eğitim örgütlerinin genel amaçlarından biri ise, toplumun değer yargılarını gelecek nesillere aktarmaktır (Demirtaş ve Ekmekyapar, 2012, s.526). Toplumu dizayn eden ve geleceğe taşıyacak olan eğitim örgütü, onu yaşatacak olan insanı yetiştirir ve hayata hazırlar (Balay, 2014, s.2). Çalışanların değişim ve gelişime erken tepki verecek şekilde esnek özelliklere sahip olmasının yanında, oluşturulan örgütsel değerlere de bağlı kalması, örgütsel başarının sürdürülebilmesi açısından da önemlidir (Öztop ve Vurgun, 2011, s.218). İnsan ve hizmetin ağırlıklı olduğu eğitim örgütlerinin yönetiminde doğru, uygun ve tutarlı kararlara varılabilmesi, yönetici ve öğretmenin alanına ilişkin bilgi ve becerileri kadar sahip olduğu iyi, doğru ve güzel anlayışı ile de ilgilidir (Aydın, 2016, s.194).

Bütün örgütlerde olduğu gibi, okullarda da öğretmenlerin sahip olduğu değerler ve tutumlar okulun işleyişinde oldukça önemlidir (Lavakov, 2016, s.149). Öğretmenlerin mesleki karar, davranış ve ilişkilerinde merkeze alacakları değerlere ilişkin yargılarının yanı sıra, iş hayatıyla ilişkili bakış açıları, örgütün gelişimi açısından büyük önem arz etmektedir (Pehlivan'dan aktaran Balay, 2014, s.2). Örgütlerinin belli birtakım değerleri dikkate aldığını ve buna göre kurallar belirlediğini bilen öğretmenler, örgüt uygulamalarını da buna göre değerlendirmektedirler (Altınkurt ve Yılmaz, 2010). Bir kavram olarak başarıyı tanımlayan ve başarıya ulaşmanın standardını belirleyen değerler, aynı zamanda örgütte kimin ne kadar hızlı yükseleceğinin belirlenmesinde de önemli rol oynar (Doğan, 2013).

Temel girdisi olan işleneni ve bu girdiyi işleyeni insan olan eğitim kurumlarında değerlerin önemi yadsınamaz. Özellikle işleyen konumunda olan öğretmenlerin örgütsel ve bireysel değerlere ne düzeyde sahip olduğu, işlenen konumunda olan öğrenci niteliklerinin belirlenmesinde etkili olacaktır. Öğretmenlerin; okulda sosyal yaşamı tesis eden kuralların herkese adil bir şekilde uygulanması, emeğe saygı gösterilmesi, iyilik, 
eşitlik, özkontrol, iç huzur, sorumluluk alma, iş arkadaşları ile uyum içinde olma, zorda kalanlara yardım etme gibi değerlerin öğretmenin hem kendisine, hem okul örgütüne hem de öğrencilere yansımalarının olması beklenir. Ortaöğretim çağındaki gençlerin rol modeli olacak öğretmenlerin değerlerden yoksun olması beklenemez. Değerlerden yoksun olan öğretmenin değerden yoksun öğrencisi; değerlerle donanık olan öğretmenin de değerlerle donanık öğrencisi olması kaçınılmaz gibi görünmektedir. Öğretmen-öğrenci etkileşimi, zamanla bütün toplumu saracak ve bu değerlere sahip olma ya da sahip olmama durumu, toplumsal bir özelliğe bürünecektir. Değerlerden yoksun bir toplum tasavvur edilemeyeceği için öğretmenlerin güçlü değerlere sahip olması beklenir.

$\mathrm{Bu}$ açıklamalar 1şığına bu araştırmanın amacı, lise öğretmenlerinin örgütsel ve bireysel değerlerine yönelik algilarının belirlenmesidir. $\mathrm{Bu}$ ana amaç ekseninde aşağıdaki sorulara cevaplar aranmıştır:

1. Lise öğretmenlerinin kendi örgütsel ve bireysel değerlerine ilişkin algıları hangi düzeydedir?

2. Bu algilar;
a. Cinsiyete
b. Yapılan göreve
c. Çalışılan ilçeye
d. Yaşa
e. Hizmet süresine
f. Branşa göre anlamlı farklılıklar göstermekte midir?

\section{Yöntem}

\section{Araştırma Modeli}

$\mathrm{Bu}$ araştırma tarama modelinde tasarlanmıştır. Tarama modelleri, olayları ve olguları geçmişte ya da halen var olduğu şekliyle betimlemeyi amaçlayan yaklaşımlardır (Karasar, 2003, s.77; Büyüköztürk-Kılıç Çakmak vd., 2016, s.177). Bu tarama modeline göre liselerde görev yapmakta olan öğretmenlerin örgütsel ve bireysel değer algı düzeyleri ölçülmüştür. 


\section{Çalışma Grubu}

Araştırmanın evrenini Kahramanmaraş ili Dulkadiroğlu ve Onikişubat merkez ilçelerinde 2016-2017 öğretim yılında eğitim-öğretim faaliyetlerine devam eden lise öğretmeleri oluşturmaktadır. Bu iki merkez ilçede 2016-2017 öğretim yılında faaliyet gösteren 58 lise ve bu liselerde görev yapan 2333 öğretmen bulunmaktadır.

Araştırmada küme örnekleme yoluna gidilmiştir. Dulkadiroğlu ve Onikişubat merkez ilçelerinde eğitim öğretime devam eden 58 lise arasinda tesadüfi örnekleme yoluyla 15 lise seçilmiş (Dulkadiroğlu ilçesinden 7; Onikişubat ilçesinden 8 lise) ve bu liselerde görev yapan bütün müdür yardımcısı ve öğretmenlere ölçek uygulanmıştır. Uygulamalar sonucunda 303 adet değerlendirilebilir nitelikte ölçek elde edilmiştir.

\section{Veri Toplama Araçları}

Araştırmada Yılmaz"ın (2007) geliştirdiği 25 madde içeren Değerlere Göre Yönetim Ölçeğinin, Demirtaş ve Ekmekyapar (2012) tarafında açımlayıcı ve doğrulayıcı faktör analizi uygulanmış formu kullanılmıştır. Son hali ile ölçek, örgütsel (5 madde) ve bireysel (7 madde) değerleri ölçmeye yönelik 12 madde içermektedir. Demirtaş ve Ekmekyapar'ın (2012), doğrulayıc faktör analizi sonucunda ulaştıkları bulgular, ölçeğin uyum iyiliği değerlerinin mükemmele yakın olduğunu göstermiştir. Ölçek maddeleri katılımcıların görüşlerini, Tamamen Katılıyorum (5)'dan Asla Katılmıyorum (1)'a doğru sıralanan bir düzen içerisinde belirlemeye olanak sunmaktadır. Bu araştırma kapsamında ölçeğe Doğrulayıcı Faktör Analizi (DFA) uygulanmış ve ölçeğin Örgütsel ve bireysel değerler boyutlarını içeren yapısının kabul edilebilir düzeyde uyum iyiliği değerlerine sahip olduğu görülmüştür $\left(X^{2} / \mathrm{df}=2,103\right.$; GFI=,866; AGFI= ,780; $\mathrm{CFI}=, 958$; $\mathrm{NFI}=, 924$; $\mathrm{TLI}=, 948$; $\mathrm{RMSEA}=, 096$ ve $\mathrm{SRMR}=, 036$ ).

Yapı geçerliğini belirlemek amacıyla ölçeğe önce açımlayıcı faktör analizi uygulanmıştır. KMO (.945) ve Barlet's Test of Sphericity (2330.759; $\mathrm{df}=66 ; \mathrm{p}=.000)$ değerleri verilerin yeterli örneklem büyüklügüne ulaştığını ve faktör analizi yapmaya uygun olduğunu göstermektedir. Faktör analizinde. $40^{\prime}$ ın altında madde yük değeri alan; üçten az madde içeren bir faktör kapsamında yer alan ve iki faktörde de birbirine 
yakın değerler alan maddeler ölçekten çıkarılmıştır. Bu işlem sonucunda iki faktör ve on iki madde içeren bir yapı elde edilmiştir. "Bireysel Değerler" adı verilen birinci faktör varyansın \%33.823'ünü. "Örgütsel Değerler" adı verilen ikinci faktör de \%29.598'ini açıklamaktadır.

\section{Verilerin Analizi}

Örgütsel Değerler ölçeğinden elde edilen müdür yardımcısı ve öğretmen algılarının sözlü ifadeler hâline dönüştürülmesi için aralık değerleri hesaplanmıştır $(5-1=4 ; 5 / 4=0,80)$. Bu bağlamda değer aralıkları; 5,00-4,21 "Tamamen Kat1lyorum" ; 3,41-4,20 "Kat1lyorum" ; 2,61-3,40 “Orta Düzeyde Katıliyorum" ; 1,81-2,60 “Katılmıyorum" ve 1,00-1,80 “Hiç Katılmıyorum" şeklinde yorumlanmıştır. Verilerin analizinde algıları betimlemek amacıyla aritmetik ortalama ve standart sapma puanları dikkate alınmıştır. Ölçekten elde edilen veriler ikili gruplamaların olduğu durumlarda t testi; ikiden fazla gruplamaların olduğu durumlarda tek yönlü varyans analizi uygulanarak grup ortalamaları arasında anlamlı farklılıkların olup olmadığını test edilmiştir. Ayrıca, yaş ve görevdeki hizmet süresinin algılar üzerindeki etkisini araştırmak için de regesyon analizi yapılmıştır.

\section{Bulgular}

Araştırmaya katkı sağlayan 303 müdür yardımcısı ve öğretmenin Örgütsel Değerler Ölçeğine vermiş oldukları yanıtlara göre Örgütsel ve Bireysel değerlerin maddeler, boyutlar ile ölçek toplamında ortaya çıan ortalama ve standart sapma değerleri Tablo 1'de yer almaktadır.

Katılımcıların kendi okullarında egemen olan örgütsel değerlere yönelik algı ortalamaları ölçek genelinde ( $\mathrm{X}=3,741)$, Örgütsel Değerler boyutunda $\left({ }^{X}=3,623\right)$ ve Bireysel Değerler boyutunda ( $\left.X=3,859\right)$ "Katıllyorum" düzeyinde $(X=3,41-4,20)$ gerçekleşmiştir. Boyutlar açısından bir değerlendirme yapılacak olursa müdür yardımcları ve öğretmenler kendi okullarında bireysel değerlerin örgütsel değerlere nispeten daha baskın olduğu algısına sahiptirler. 
Tablo 1. Değerlerle Yönetim Ölçeği Ortalamaları ve Standart Sapmalarn

\begin{tabular}{lll}
\hline Ölçekler & - & XS \\
\hline Kurallar herkese eşit olarak uygulanır. & 3.663 & 1.187 \\
Her türlü çalışmanın başarılı bir şekilde tamamlanmasına özen & 3.789 & .957 \\
gösterilir. & 3.528 & 1.130 \\
Çok çalışanlar topluluk önünde takdir edilir. & 3.574 & 1.110 \\
Demokratik bir ortam vardır. & 3.561 & 1.117 \\
Yarar ve hizmetlerin dağılımında eşit davranılır. & 3.623 & .952 \\
Örgütsel Değer Toplam & 3.970 & .954 \\
Diğer insanlara iyilik yapmak erdem olarak görülür. & 3.749 & .958 \\
Kişilerin oto kontrolünü sağlaması önemsenir. & 3.634 & 1.058 \\
Yapılan işlerde önce iç huzur düşünülür. & 3.822 & .964 \\
Verilen sözlere sadık kalınmasına önem verilir. & 3.729 & 1.032 \\
Arkadaş ve iş grubunda sorumluluktan kaçınılmaz. & 3.980 & .899 \\
Çalışanlar arasında uyumun gerektiği düşünülür. & 4.129 & .903 \\
Zor durumda olan kişilere yardım edilir. & 3.859 & .806 \\
Bireysel Değer Toplam & 3.741 & .840 \\
\hline Ölçek Toplam & & \\
\hline
\end{tabular}

Örgütsel Değerler boyutunda en yüksek algılar "Her türlü çalışmanın başarılı bir şekilde tamamlanmasına özen gösterilir." maddesinde ortaya çıkmıştır ( $\bar{X}=3,859)$. İkinci sırada "Kurallar herkese eşit olarak uygulanır." maddesi yer almıştır ( $\bar{X}=3,663)$. Bu boyutun en düşük algı ortalamaları "Çok çalışanlar topluluk önünde takdir edilir." maddesinde ortaya çıkmıştır ( $\mathrm{X}=3,528)$.

Bireysel Değerler boyutunda en yüksel algılar "Zor durumda olan kişilere yardım edilir." maddesinde ortaya çıkmıştır ( $X=4.129$ ). Aynı zamanda ölçeğin de en yüksek ortalamasını gösteren bu maddeyi "Çalışanlar arasında uyumun gerektiği düşünülür." maddesi izlemiştir ( $X$ $=3,980$ ). Boyutun en düşük ortalamalarına sahip olan maddeler sırasıyla "Yapılan işlerde önce iç huzur düşünülür." ( $X=3.634$ ) ve "Arkadaş ve iş grubunda sorumluluktan kaçınılmaz." ( $\bar{X}=3.729$ ) maddeleri olmuştur. 
Katılımcı görüşlerinin cinsiyet açısından anlamlı farklılıklar gösterip göstermediğini belirlemek amacıyla $\mathrm{t}$ testi uygulanmış ve bulgular Tablo 2 'de verilmiştir.

Tablo 2. Cinsiyet Açısından Değer Algılarına ilişkin t Testi Sonuçları

\begin{tabular}{|c|c|c|c|c|c|c|c|}
\hline Ölçek/Boyut & Cinsiyet & $\mathbf{N}$ & $\bar{X}$ & SS & $t$ & SD & $\mathrm{p}$ \\
\hline Örgütsel & Kadın & 141 & 3,567 & 981 & \multirow{2}{*}{,- 950} & \multirow{2}{*}{301} & \multirow{2}{*}{,343 } \\
\hline Değerler & Erkek & 162 & 3,672 & ,926 & & & \\
\hline Bireysel & Kadın & 141 & 3,797 & 759 & \multirow{2}{*}{$-1,243$} & \multirow{2}{*}{301} & \multirow{2}{*}{,215 } \\
\hline Değerler & Erkek & 162 & 3,913 & 843 & & & \\
\hline \multirow{2}{*}{ Toplam } & Kadın & 141 & 3,682 & 824 & \multirow{2}{*}{$-1,136$} & \multirow{2}{*}{301} & \multirow{2}{*}{,257 } \\
\hline & Erkek & 162 & 3,792 & 852 & & & \\
\hline
\end{tabular}

${ }^{* *} \mathrm{p}<.01$

Hem Örgütsel Değerler hem de Bireysel Değerler boyutlarında erkek katılımcıların algıları kadın katılımcılardan daha yüksek olmasına rağmen iki boyutta ve ölçek toplamında ortaya çıkan bu farklılık istatiksel olarak anlamlı bulunmamıştır. Bu bulgulara göre, cinsiyet değişkeni örgütsel ve bireyler değerler üzerinde anlamlı bir farklılık oluşturmamıştir.

Dağıtılan ölçekleri yanıtlayan okul müdürü olmamıştır. Toplam 303 olan katılımcidan 20 müdür yardımcısı ve 282 öğretmen görevlerini belirtirken bir katılımcı bu soruya yanıt vermemiştir. Görev değişkeni açısindan uygulanan $\mathrm{t}$ testi bulguları Tablo 3 'te yer almaktadır.

Tablo 3. Görev Açısından Değer Algılarına ilişkin t Testi Sonuçları

\begin{tabular}{|c|c|c|c|c|c|c|c|}
\hline Ölçek/Boyut & Cinsiyet & $\mathbf{N}$ & $\bar{X}$ & SS & $t$ & SD & p \\
\hline \multirow{2}{*}{$\begin{array}{l}\text { Örgütsel } \\
\text { Değerler }\end{array}$} & $\begin{array}{l}\text { Müdür } \\
\text { Yrd. }\end{array}$ & 20 & 3,970 & ,897 & \multirow{2}{*}{1,717} & \multirow{2}{*}{300} & \multirow{2}{*}{, 087 } \\
\hline & Öğretmen & 282 & 3,593 & ,951 & & & \\
\hline \multirow{2}{*}{$\begin{array}{l}\text { Bireysel } \\
\text { Değerler }\end{array}$} & $\begin{array}{l}\text { Müdür } \\
\text { Yrd. }\end{array}$ & 20 & 4,129 & ,579 & \multirow[t]{2}{*}{1,572} & \multirow[t]{2}{*}{300} & \multirow[t]{2}{*}{,117 } \\
\hline & Öğretmen & 282 & 3,836 & ,816 & & & \\
\hline \multirow[t]{2}{*}{ Toplam } & $\begin{array}{l}\text { Müdür } \\
\text { Yrd. }\end{array}$ & 20 & 4,049 & 711 & \multirow[t]{2}{*}{1,729} & \multirow[t]{2}{*}{300} & \multirow[t]{2}{*}{,085 } \\
\hline & Öğretmen & 282 & 3,715 & ,843 & & & \\
\hline
\end{tabular}

${ }^{* *} \mathrm{p}<.01$ 
Tablo 3'te yer alan bulgular müdür yardımcısı ve öğretmen algıları arasında anlamlı bir farklılık olmadığını göstermektedir. Ancak her iki boyutta da müdür yardımcılarının algı ortalamaları öğretmenlerden biraz daha yüksektir.

Kahramanmaraş'ın iki merkez ilçesinde görev yapan katılımcı algıları arasında anlamlı farklılıkların olup olmadığını test etmek üzere uygulanan $\mathrm{t}$ testi bulguları Tablo 4 'te yer almaktadır.

Tablo 4. İlçe Açısından Değer Algılarına ilişkin t Testi Sonuçları

\begin{tabular}{llllllll}
\hline Ölçek/Boyut & İlçe & $\mathbf{N}$ & $\overline{\boldsymbol{X}}$ & SS & $\mathbf{t}$ & SD & $\mathbf{p}$ \\
\hline Örgütsel De- & Dulkadiroğlu & 106 & 3,851 &, 884 & \multirow{2}{*}{$3,099^{* *}$} & \multirow{2}{*}{301} & \multirow{2}{*}{002} \\
ğerler & Onikişubat & 197 & 3,501 &, 967 & & & \\
\hline Bireysel & Dulkadiroğlu & 106 & 4,082 &, 770 & \multirow{2}{*}{$3,605^{* *}$} & \multirow{2}{*}{301} & \multirow{2}{*}{000} \\
Değerler & Onikişubat & 197 & 3,739 &, 801 & \multirow{2}{*}{, 001} \\
\hline \multirow{2}{*}{ Toplam } & Dulkadiroğlu & 106 & 3,967 &, 787 & \multirow{2}{*}{$3,493^{* *}$} & \multirow{2}{*}{301} & \multirow{2}{*}{001} \\
& Onikişubat & 197 & 3,620 &, 844 & \multirow{2}{*}{,}
\end{tabular}

${ }^{* *} \mathrm{p}<.01$

Örgütsel Değerler ortalamaları açısından Dulkadiroğlu ilçesinde görev yapan katılımcıların algı ortalamaları $(X=3,851)$ Onikişubat ilçesinde görev yapan katılımcıların algı ortalamalarından $(X=3,501)$ anlamlı düzeyde daha yüksektir ve bu farklılık istatiksel açıdan ,01 düzeyinde anlamlıdır $(p=, 002)$. Bireysel Değerler boyutunda da birinci ilçede görev yapanların ortalamaları $(\bar{X}=4,082)$ ikinci ilçede görev yapanların ortalamalarından $(\bar{X}=3,739)$ anlamlı düzeyde daha yüksek olduğundan aradaki farklılık, 01 düzeyinde anlamlı bulunmuştur $(\mathrm{p}=, 000)$. İki boyutta ortaya çıkan farklılık ölçek toplamında da aynen korunmuştur. Ölçek toplamında Dulkadiroğlu ilçesi ortalamaları $(X=3,967)$ Onikişubat ilçesi ortalamalarından $(\bar{X}=3,620)$ anlamlı düzeyde daha yüksektir $(p=, 002)$.

Yaş değişkeninin katılımcıların değerleri üzerinde anlamlı bir etkisinin olup olmadığını test etmek amaciyla uygulanan regresyon analizine ait veriler Tablo 5 'te verilmiştir. 
Tablo 5. Yaş Değişkeninin Örgütsel Değerler Üzerindeki Etkisi

\begin{tabular}{lllllll}
\hline Değişken & $\mathbf{B}$ & $\mathbf{R}$ & $\Delta \mathbf{R}^{2}$ & $\boldsymbol{\beta}$ & $\mathbf{t}$ & $\mathbf{P}$ \\
\hline Sabit & 3,626 & & & & 32,167 &, 000 \\
\hline Yaş &, 003 &, 065 &, 004 &, 065 & 1,127 &, 261 \\
\hline
\end{tabular}

Bağımlı Değişken: Değerler

${ }^{* *} \mathrm{p}<.01$

Tablo 5, yaş değişkenin Değerler üzerinde anlamlı bir etkisinin olmadığını ortaya koymaktadır ( $R=, 065, R^{2}=, 004$ ve $\left.\mathrm{p}>.05\right)$.

Müdür yardımcılığı ve öğretmenlikteki hizmet süresinin ya da ikisinin toplamının katılımcıların değerleri üzerinde anlamlı bir etkisinin olup olmadığını test etmek amacıyla uygulanan regresyon analizine ait veriler Tablo 6'da verilmiştir.

Tablo 6. Hizmet süresi Değişkeninin Örgütsel Değerler Üzerindeki Etkisi

\begin{tabular}{lllllll}
\hline Değişken & $\mathbf{B}$ & $\mathbf{R}$ & $\Delta \mathbf{R}^{2}$ & $\boldsymbol{\beta}$ & $\mathbf{t}$ & $\mathbf{P}$ \\
\hline Sabit & 3,817 & & & & 40,173 &, 000 \\
\hline Hizmet Süresi &,- 005 &, 053 &, 003 &,- 053 &,- 926 &, 355 \\
\hline
\end{tabular}

Bağımlı Değişken: Değerler

${ }^{* *} \mathrm{p}<.01$

Tablo 6'da yer alan veriler hizmet süresi değişkenin Değerler üzerinde anlamlı bir etkisinin olmadığını ortaya koymaktadır $\left(R=, 053, R^{2}=, 003\right.$ ve $\mathrm{p}>.05)$.

Katılımcıların öğretmenlikteki branşları çok çeşitlilik göstermekteydi. Bu branşlar; dil, sanat, bilişim, sayısal, sözel, meslek olmak üzere altı grupta toplandı. Bu altı grubun algı ortalamaları arasında anlamlı farklılıkların olup olmadığını test etmek amacıyla uygulanan tek yönlü varyans analizi sonuçları Tablo 7'de verilmiştir.

Örgütsel Değerler ve Bireysel Değerler boyutlarında ve buna bağlı olarak ölçek toplamında katılımcıların branşları açısından grup ortalamaları arasında istatiksel açıdan anlamlı bir farklılık ortaya çıkmamıştır. $\mathrm{Bu}$ bulgu, değerlerin branş değişkeni ile bağlantılı olmadığını ortaya koymaktadir. 
Tablo 6. Hizmet süresi Değişkeninin Örgütsel Değerler Üzerindeki Etkisi

\begin{tabular}{|c|c|c|c|c|c|c|}
\hline Ölçek/Boyut & $\begin{array}{l}\text { Varyansın } \\
\text { Kaynağ1 }\end{array}$ & $\begin{array}{l}\text { Kareler } \\
\text { Toplamı }\end{array}$ & sd & $\begin{array}{l}\text { Karelerin } \\
\text { Ort. }\end{array}$ & $\mathbf{F}$ & p \\
\hline \multirow{3}{*}{$\begin{array}{l}\text { Örgütsel } \\
\text { Değerler }\end{array}$} & Gruplar arası & 8,451 & 5 & \multirow{3}{*}{$\begin{array}{l}1,690 \\
, 893\end{array}$} & \multirow{3}{*}{1,892} & \multirow{3}{*}{,096 } \\
\hline & Gruplar içi & 265,347 & 297 & & & \\
\hline & Toplam & 273,798 & 302 & & & \\
\hline \multirow{3}{*}{$\begin{array}{l}\text { Bireysel } \\
\text { Değerler }\end{array}$} & Gruplar arası & 4,863 & 5 & \multirow{3}{*}{$\begin{array}{l}, 973 \\
, 644\end{array}$} & \multirow{3}{*}{1,510} & \multirow{3}{*}{ 187 } \\
\hline & Gruplar içi & 191,340 & 297 & & & \\
\hline & Toplam & 196,203 & 302 & & & \\
\hline \multirow{3}{*}{ Toplam } & Gruplar arası & 6,171 & 5 & \multirow{3}{*}{$\begin{array}{l}1,234 \\
, 696\end{array}$} & \multirow{3}{*}{1,773} & \multirow{3}{*}{ 118 } \\
\hline & Gruplar içi & 206,723 & 297 & & & \\
\hline & Toplam & 212,894 & 302 & & & \\
\hline
\end{tabular}

${ }^{* *} \mathrm{p}<.01$

\section{Tartışma, Sonuç ve Öneriler}

Okulların değerlerle yönetilmesine yönelik okul yöneticisi ve öğretmenlerin algılarını ortaya çıkarmayı amaçlayan bu araştırmada katılımcıların değerlere yönelik algıları ortalamanın üzerinde çıkmıştır. Beşli likert tipi ölçek ile ölçülen algılar dördüncü aralıkta (Katılıyorum) gerçekleşmiştir. Okullarda bireysel değerlerin örgütsel değerlerden daha yüksek algılandığı bulgusuna ulaşılmıştır. Bu bulgu, Demirtaş ve Ekmekyapar (2012)'ın yapmış olduğu araştırma bulgularıyla örtüşmektedir. Benzer şekilde, Kılınç (2012), değerlerin bireysel ve örgütsel düzeyde önemli olduğu bulgusuna ulaşmıştır. Müdür yardımcısı ve öğretmenlerin kendi okullarında bireysel değerlerin örgütsel değerlere nispeten daha yüksek düzeyde algılaması, örgütsel değerlerin benimsenmesi ve içselleştirilmesi açısından okul yönetimlerinin çaba harcamaları gerekliliğini ortaya koymaktadir.

Müdür yardımcısı ve öğretmenler en fazla Bireysel Değerler boyutunda yer alan "Zor durumda olan kişilere yardım edilir." ve "Çalışanlar arasında uyumun gerektiği düşünülür." maddelerine katılmışlardır. Zor durumda kalanlara yardım etme özelliği bütün doğu toplumları gibi Türk toplumunda da karşılık gören bir değerdir. Araştırmaya katılım sağlayan eğitimciler, bu değerin okul ortamında korunduğu algisına sahiptirler. Yine doğulu kültürlerin toplum ile çatışmama, başka bir yö- 
nüyle toplumla uyum içerisinde yaşama değerinin okullarda da korunduğu ortaya çımıştır.

En düşük katılımın olduğu iki madde Örgütsel Değerler boyutunda yer alan "Çok çalışanlar topluluk önünde takdir edilir." ve "Yarar ve hizmetlerin dağılımında eşit davranılır." maddeleri olmuştur. Çalışanların başarılarının topluluk önünde takdir edilmesi, bu performansı sergileyen eğitim çalışanlarına verilen değerin herkese gösterilmesi konusunda okul toplumun yeterli hassasiyet göstermediği söylenebilir. Bu değerin korunması halinde en düşük katılımın görüldüğü örgütsel adaleti dile getiren maddeye katılımın da yüksek olması beklenebilir. Zira çok çalışanlar topluluk önünde takdir edildiğinde yarar ve hizmetlerin dağ1lımında da eşitlik sağlanması söz konusu olabilir.

Kahramanmaraş ili iki merkez ilçesinde müdür yardımcısı ve öğretmenlerin örgütsel ve bireysel değer algıları anlamlı derecede farklılık göstermektedir. Fakat bu bulgu Taştan'ın (2010) bulguları ile çelişmektedir. Bu çelişkinin sebebi sosyo-ekonomik olarak illerin karşılaştırılmasından kaynaklanabilir. Kahramanmaraş'ın iki merkez ilçelerinden Onikişubat sosyo-ekonomik açıdan Dulkadiroğlu ilçesine göre daha fazla gelişmişlik özelliği göstermektedir. Bu bulgu, sosyo-ekonomik gelişmişlik düzeyi ile değerler arasında negatif bir ilişki olduğuna işaret etmektedir. Buradan yola çıkarak toplumların gelişmesi ve refah artışı ile birlikte değerlerde bir çözülme ya da bozulmanın ortaya çıtığını ileri sürmek mümkün görünmektedir. Sosyo-ekonomik düzeyin artmasıyla birlikte değerlerde çözülme ve bozulmanın sebepleri bir başka araştırma konusu olabilir.

Cinsiyet değişkeni açısından örgütsel ve bireysel değerlerde istatistiksel olarak anlamlı bir fark gözükmemekle birlikte erkeklerin örgütsel ve bireysel değer algıları, kadınların algılarından daha yüksektir. Araştırmanın bu bulgusunu destekleyen ve çelişen araştırmalar literatürde mevcuttur. Bu bulgu, Altunay ve Yalçınkaya (2011) ve Eşberk Başyayla (2016)' nın araştırma bulgularıyla çelişirken; Sağnak (2005) ve Taştan (2010)'ın araştırma bulgularıyla uyum göstermektedir. Kadın katılımcıların örgütsel ve bireysel değer algılarının düşük olması bazı ihtiyaçlarının karşılanmamasından kaynaklanabilir. Kadınların örgütsel ve bireysel değer algilarının yükseltilmesi için ders saatlerinin ve nöbet günlerinin 
ayarlanması gibi bir takım düzenlemeler yapılması gerektiği söylenebilir.

Müdür yardımcıları ve öğretmenler arasında değerler açısından anlamlı bir farklılık gözükmemektedir. Fakat müdür yardımcılarının örgütsel ve bireysel değer algılarının öğretmenlerden daha yüksek olduğu görülmektedir. Müdür yardımcılarının değer algılarının öğretmenlerden yüksek olması, örgütsel karar alma süreçlerinde aktif olmalarından kaynaklanıyor olabilir. Çalışanların da oluşturulan örgütsel değerlere katkı sağlamasıyla kurum içindeki güven ve motivasyonun artmasıyla birlikte alınan karaların ve eylemlerin kalitesi artar (Argüden, 2004, s.19). Bu bulgulardan yola çıkarak öğretmenlerin değer algılarının artırılmasına yönelik okulla ilgili karar alma süreçlerine dâhil edilmeleri sağlanabilir.

Yaş, hizmet yılı ve branş değişkenlerinin değerler üzerinde anlamlı bir farklılık göstermemesi, yaş, hizmet yılı ve branşın örgütsel ve bireysel değerler üzerinde kayda değer bir etkisinin olmadığını göstermektedir. Sezgin (2006, s.567) ve Sağnak'ın (2003) yapmış olduğu çalışmalarda mesleki kıdemle ilgili bulgular bu araştırmanın bulguları ile çelişmektedir. Son dört yılda okul yöneticiliği kazanılmış bir hak olmaktan çıkarılarak ikinci görevlendirme kapsamına alınmıştır. Milli Eğitim Bakanlığı okul müdürü, müdür başyardımcısı ve yardımcısı kadroların dört yıllık görevlendirme yapmaktadır. Bu konumlara görevlendirilecek kişilerin görev süresi dört yılla sınırlıdır. Dördüncü yılın sonunda sona eren göreve ikinci defa aday olarak başvurulabilir. Bu süreçte, o konumda görev yapan kişi, tıpkı diğer başvuru sahipleri gibi değerlendirilir eğer diğerlerinden daha yüksek puanlara ulaşırsa bu göreve atanabilir. Atanamaması durumunda öğretmenliğe geri döner. Bu durum, okul yöneticilerinin algılarının öğretmenlerden farklılaşmasının bir nedeni olabilir.

Okul yöneticileri, örgüt kültüründe değerlerin önemini dikkate alma11, örgütsel değerleri oluştururken örgüt içinde ve çevresinde yaşatılan değerleri iyi analiz etmeli ve bu değerlerle çatışmayan, tüm örgüt üyelerince kolayca benimsenebilecek ve örgütün paydaşlarınca takdirle karşılanacak değerler belirlemeye özen göstermelidir (Öztop ve Vurgun, 2011, s. 227). 


\title{
Organizational and Individual Values of High School Teachers
}

\author{
Davut Nacar - Zülfü Demirtaş
}

Sütçü Imam University - Fırat University

In today's world where cultural, social, economic and technological changes are very fast, there are difficulties in adapting to these changes. One of the expressions that we hear and use most in modern times is the loss of values and the erosion of values and the alienation of the individual to society and self. Rules and mutual relations in social life and organizations enable individuals to learn socialization and new behaviours. It is emphasized by the researchers that the environment and personality characteristics of the human shape the behaviours of the individual. In organizational life, values are considered to be important for the behavior of employees and the organization and this importance is increasing. Organizational values are tools that contribute to the organization's activities and to increase its success. As in all organizations, the values and attitudes of teachers in schools are very important in the functioning of the school. Besides the judgments of the teachers about the values that will be taken to the centre in their professional decisions, behaviours and relations, the perspectives associated with the business life are of great importance for the development of the organization. The importance of values cannot be denied in the educational institutions with basic input and the people who process this input. In particular, the extent to which teachers who are in a functioning position have organizational and individual values will be effective in determining the qualifications of students in the position they are in. In the light of these explanations, the aim of this study is to determine the perceptions of high school teachers on their organizational and individual values.

\section{Method}

This research was designed in the screening model. The universe of the study consisted of high school teachers who continue their education 
activities the 2016-2017 academic year in the central districts of Dulkadiroğlu and Onikişubat in the province of Kahramanmaraş. In this research, cluster sampling was made. In the study, the exploratory and confirmatory factor analysis form of the Management Scale according to Values, which was developed by Yılmaz (2007), and Demirtaş and Ekmekyapar (2012) was used.

\section{Finding and Discussion}

In this study, which aimed to reveal the perceptions of school administrators and teachers about managing values of schools, the perceptions of participants about values increased above the average. The deputy director and the teachers participated in the articles which included the most individual values dimension: "People who are difficult are also helped" and "It is considered that there is a need for harmony between employees". The two items with the lowest participation are the ve Multi- workers are appreciated in front of the community "and önünde Equal treatment of benefits and services are treated equally eşit in the Organizational Values dimension. Organizational and individual perceptions of deputy director and teachers in two central districts of Kahramanmaraş province differ significantly. Although there is no statistically significant difference in organizational and individual values in terms of gender variable, men's perceptions of organizational and individual values are higher than women's perceptions. There is no significant difference between the deputies and teachers in terms of values. However, the organizational and individual value perceptions of vice principals are higher than the teachers. The fact that the value perception of the deputies is higher than the teachers may be due to their active participation in organizational decision making processes. School administrators should take into account the importance of values in the organizational culture, analyze the values living in and around the organization while creating the organizational values, and make sure to determine the values that do not conflict with these values, can be easily adopted by all members of the organization and appreciated by the stakeholders of the organization. 


\section{Kaynakça / References}

Alev, S. ve Karakuş, M. (2016). Öğretmenlerin bireysel ve örgütsel değerleri ile izlenim yönetimi taktikleri seçimi arasındaki ilişki düzeyi. Mustafa Kemal Üniversitesi Sosyal Bilimler Enstitüsü Dergisi, 13(33), 137-152.

Altunay, E. ve Yalçınkaya, M. (2011). Öğretmen adaylarının bilgi toplumunda değerlere ilişkin görüşlerinin bazı değişkenler açısından incelenmesi. Kuram ve Uygulamada Eğitim Yönetimi. 17(1), 5-28.

Tolay, S. ve Yeşil, Ü. (2016). Örgüt geliştirmenin temel değerleri ve etik ilkeleri. Dalkılıç, O. S. (Ed.), Örgüt Geliştirme. Ankara: Nobel Yayincilik.

Yılmaz, .A. (2004). Geleceği şekillendirmek. Ankara: Rota Yayınları

Yapıc1, M. ve Zeren Nalinci, G. (2015). Değerler eğitimi ve insan ilişkileri. Avşaroğlu, S. (Ed), Kişisel Gelişim ve İnsan İlişkileri (s. 73-90). Ankara: Eğiten Kitap.

Aydın, İ. (2016). Eğitim ve öğretimde etik. Ankara: Pegem Akademi Yayınc1lik.

Aydın, İ. (2016). Yönetsel mesleki ve örgütsel etik (7.Bask1). Ankara: Pegem Akademi Yayıncilı:

Balay, R. (2014). Yönetici ve öğretmenlerde örgütsel bağlllık (2. Bask1). Ankara: Pegem Akademi Yayıncilik:.

Boyacı, M. ve Güven, M. (2017). Kişilik ve değerler. Servet Özdemir ve Necati Cemaloğlu (Ed.), Örgütsel Davranış ve Yönetimi (s. 55-78). Ankara: Pegem Akademi Yayıncılık.

Büyüköztürk, Ş., K1lıç Çakmak, E., Akgün, Ö.E., Karadeniz, Ş. ve Demirel, F. (2016). Bilimsel araştırma yöntemleri. Pegem Akademi: Ankara

Eşberk Başyayla, Y. (2016). Lise öğretmenlerinin bireysel ve örgütsel değerlerinin uyumu. Yayımlanmamış Yüksek Lisans Tezi, Akdeniz Üniversitesi Ĕ̆itim Bilimleri Enstitüsü, Antalya.

Demirtaş, Z. ve Ekmekyapar, M. (2012). İlköğretim okul yöneticilerinin değerlere dayalı yönetim uygulamalarının okul kültürüne etkisi. Kuram ve Uygulamada Ĕ̆itim Yönetimi, 18(4), 523-544.

Doğan, E. Ş. (2013). Örgüt kültürü ve örgütsel bağlllkk. Türkmen Kitapevi: İstanbul. 
Hodgkinson, C. R. (2008).Yönetim felsefesi, örgütsel yaşamda değerler ve motivasyon. (İ. Anıl ve B. Doğan, Çev.) İstanbul: Beta Yayım.

Karasar, N. (2003). Bilimsel araştırma yöntemi. Nobel Yayın Dağıtım: Ankara

Kılıç, F. (2012). Ortaöğretim okullar yöneticilerinin değgrlerle yönetime ilişkin algıları. Yayımlanmış Yüksek Lisans Tezi, Fırat Üniversitesi, Elazığ.

Lavakov, A. (2016). Antecedents of organizational commitment among faculty: an exploratory study. Tertiary Education and Management, 149-170, http://dx.doi.org/10.1080/13583883.2016.1177583

Memduhoğlu, H. B. (2011.) Liselerde farklılıkların yönetimi: Bireysel tutumlar, örgütsel değerler ve yönetsel politikalar. Mersin Üniversitesi Ĕ̆itim Fakültesi Dergisi, 7 (2), 37-53.

Öztop, S. ve Vurgun, L. (2011). Yönetim ve örgüt kültüründe değerlerin önemi. Süleyman Demirel Üniversitesi İktisadi ve İdari Bilimler Fakültesi Dergisi, 16(3), 217-230.

Rokeach, M. (1968). The role of values in public opinion research. The Public Opinion Quarterly, 32 (4), 547-559, https://doi.org/10.1086/267645.

Sağnak, M. (2005). İlköğretim okullarında görevli yönetici ve öğretmenlerin örgütsel değerlere ilişkin algıları ile bireysel değerleri arasindaki uyum düzeyi. Ĕ̈itim ve Bilim, 30(136), 31-38.

Sağnak, M. (2003). İlköğretim okullarında görevli yönetici ve öğretmenlerin örgütsel değerlere ilişkin algıları ile bireysel değerleri arasındaki uyum düzeyi. Yayınlanmamış Doktora Tezi, Abant İzzet Baysal Üniversitesi, Sosyal Bilimler Enstitüsü, Bolu.

Sezgin, F. (2006). İlköğretim Okulu Öğretmenlerinin Birey-Örgüt Değer Uyumuna İlişkin Algıları. Kuram ve Uygulamada Eğitim Yönetimi, $48,557-583$.

Taştan, M. (2010). Türkiye'deki resmi ve özel ilköğretim okulu öğretmenlerinin bireysel değerleri ile okulun örgütsel değerleri arasındaki uyum düzeyi. Kuram ve Uygulamada Eğitim Yönetimi, 16(1), 113148. 
Taymur, İ. ve Türkçapar, M. H. (2012). Kişilik: tanımı, sınıflaması ve değerlendirmesi. Psikiyatride Güncel Yaklaşımlar, 4(2), 154-177, doi:10.5455/cap.20120410.

Turgut, T. (1998). Örgütsel davranışta değerlerin yeri. Suna Tevrüz (Ed.), Endüstri ve Örgüt Psikolojisi-II (ss. 35-48). Ankara: Türk Psikologlar Derneği Yayınları.

Tutar, H. (2016). Örgütsel davranış: Örgüt teorileri ve çağdaş yaklaşımlar açısından. Ankara: Detay Yayıncılık.

Yılmaz, K. (2007). İlköğretim okul yönetici ve öğretmenlerinin değerlere göre yönetim ile ilgili görüşleri. Kuram ve Uygulamada Ĕ̆itim Yönetimi, 52, 639-664.

\section{Kaynakça Bilgisi / Citation Information}

Nacar, D. ve Demirtaş, Z. (2018). Lise öğretmenlerinin örgütsel ve bireysel değerleri. OPUS-Uluslararası Toplum Araştırmaları Dergisi, 9(16), 437-455. DOI: 10.26466/opus.469281 